Калина-Теодора Гаврилів

Аспірант кафедри архітектури та реставрачії, Національний університет «Львівська політехніка», вул. С.Бандери, 12, Львів 79013, Україна

e-mail: kalyna.gavryliv@gmail.com orcid: 0000-0001-7328-8349

\title{
THE PROBLEM OF CASTLE RUINS CONSERVATION WITHIN THE RESTORATION ACTIVITIES FORMATION
}

\section{ПРОБЛЕМА РЕСТАВРАЦІЇ ЗАМКОВИХ РУЇН \\ В КОНТЕКСТІ СТАНОВЛЕННЯ РЕСТАВРАЦЙНОЇ ДІЯЛЬНОСТІ}

(C) Гаврилів К.-T., 2020

У статті розкрито історію становлення реставраційної діяльності на прикладі реставрації замкових руїн в Украӥні та Свропі в період XIX-XXI cm. Як приклад розглянуто замки у Вудстоці (Англія), Вільнюсі, Тракаї (Литва), Гайдельберзі (Німеччина), Варщаві, Іновлодзі (Польща), П'єрфоні (Франція), Олеську та Острозі (Україна). Проаналізовано позиції щодо реставрації пам'яток архітектури ряду науковців: Ежена Віолле-ле-Дюка, Алоӥза Рітля, Камілло Бойта та Яна Захватовича.

Ключові слова: реставрація, консервація, відбудова, замок, замкова руїна.

\section{Постановка проблеми}

Народна мудрість передавалася 3 вуст в вуста, історичні події записувалися літописцями, а споруди зведені з дерева і каменю, як приклади зодчества своїх епох, з роками трансформувалися під впливом людських потреб чи людської байдужості. Як окремий вид споруд розглядаємо замки.

Замки виникали на місці городищ та дитинців на стратегічно важливих територіях, далі удосконалювалися, отримуючи образ величі та могутності, згодом у зв'язку із втратою оборонних функцій трансформувалися у палаци та резиденції з мальовничими парками. Кожен наступний володар замку укріплював його, відбудовував після чергових руйнувань, вносив зміни в архітектуру та стилістику будівлі. I в один момент приходить розуміння цінності таких архітектурних об'єктів, що були створені задовго до нашої появи на світ. Вони відображають традиції будівництва, мистецькі надбання, щоденний побут епох, в які вони проіснували. Появляється потреба зберегти минуле. Власне, пам'ять про минуле $є$ закладеною у людській свідомості. «Пам'ятка архітектури» - саме такий термін вживаємо до об'єктів, що були зведені в давні часи та несуть високу історичну чи художню цінність. Пам'ятка, від слова «пам'ятати», - наголошення на тому, що пам'ятати це важливо.

Так виникає реставрація - діяльність, що спрямована на збереження архітектурних пам'яток.

Виділяють три великі ідеї реставрації: 1) відтворення первісного вигляду пам'ятки; 2) збереження об'єкта у максимально можливій недоторканності; 3) вияв та узгодження історичної та художньої цінності об'єкта. Їх можна чітко спостерігати на способах 
збереження замкових руїн. Відтак ідеї реставрації замків є найбільш дискусійними та складними у виконанні.

\section{Аналіз останніх досліджень та публікацій}

Загалом до теми теорії реставрації звертався ряд українських та зарубіжних науковців. Серед них можна виділити праці Бевза М.В. (Бевз, 2004), Лесика О.В. (2013), Прибєги Л.В (2015), Трегубової Т.С. (Трегубова, 1994), Боброва Ю.Г. (2004), Подьяпольского С.С. (Подьяпольский, 2000), Jokilehto J. (Jokilehto, 1986).

\section{Мета статті}

Розглянути історію становлення реставраційної діяльності на прикладі реставрації замків в стані руїни.

\section{Виклад основного матеріалу}

За словами Джона Раскіна (John Ruskin, 1819-1900): «Реставрація є найбільш повним видом руйнування, якого може зазнати споруда» (Ruskin, 1849), проте слід пам'ятати, що кожен період мав свій відтінок дефініції «реставрація».

Виділяють чотири етапи становлення реставрації як сфери архітектурно-будівельної діяльності (Трегубова, 1994). Перший етап - це період до усвідомлення цінності архітектурної спадщини, що тривав до початку XIX ст. Застосовуються методи оновлення та підстановки, далі - емпіричний підхід до збереження та ремонту, основне завдання - зберегти функцію будівлі. Другий етап, що припадає на середину ХІХ., - це, власне, становлення реставрації, що починається 3 стилістичних реставрацій. Метою постає відновлення стилістичної цілісності та композиційної завершеності споруди. В кінці ХІХ ст. починається третій етап: із розвитком археології і мистецтвознавства сформувався погляд на пам'ятку архітектури як на історичне джерело, науковий документ. Це період археологічних реставрацій, в основі якого є збереження пам'ятки в тому вигляді, в якому вона вціліла - іiі консервація. А в подальшому і метод аналітичних реставрацій, що поєднував стилістичні та археологічні методи. Четвертий етап, що припадає на ХX ст., відзначається становленням комплексного підходу до реставрації, враховується зв'язок пам'ятки з довкіллям.

Первинні «реставрації» завжди мали утилітарний, прагматичний характер. Старовинні споруди відновлювали не як документи історії, а як носії актуального значення з актуальними функціями. Замки слугували житлом для володарів навколишніх територій, оборонними пунктами, які повинні були постійно укріплюватися відповідно до виду воєнних дій свого періоду. Відновлення зруйнованих оборонних веж було спричинене не повагою до старожитностей чи розумінням їх художньої значущості, а зацікавленнями політичного чи прагматичного характеру. При цьому саме ці зацікавлення спричиняли і зворотню реакцію знищення «чужого»: якщо увірватися на територію замку під час облоги було складно, його просто старалися зруйнувати.

Руйнування замків було спричинене не лише військовими діями: землетруси, грози, інші стихійні лиха - природа завдавала також нищівні удари. Далі спрацьовував людський фактор - відбудувати або покинути. Королівський замок Вудсток (Woodstock Palace, England) тому приклад. В середині XVII ст. під час воєнних дій споруда була сильно пошкоджена, і іï відбудовою ніхто не займався, відтак згодом за бажанням власників іiі розібрано. Джон Ванбру (John Vanbrugh, 1664-1726), британський драматург та архітектор, намагався переконати зберегти руїни, посилаючись на їх художню цінність, а також те, як 
вони помагають сформувати та збагатити пейзаж. Це були початки становлення розуміння цінності історично сформованого середовища. Проте 1720 року руїни розібрали (Jokilehto, 1986). Місце, на якому колись розташовувався замок, сьогодні позначено постаментом.

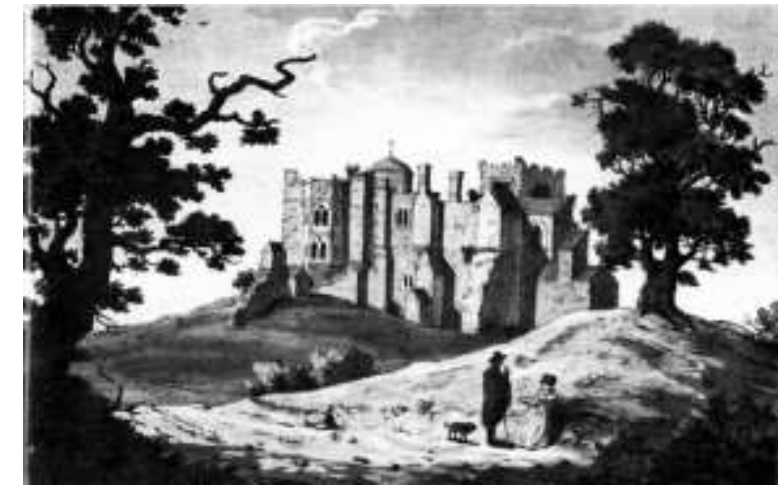

Рис. 1. Замок Вудсток. Автор невідомий, акварель, nоч. XVIII cm. (Pipe S., 2007)

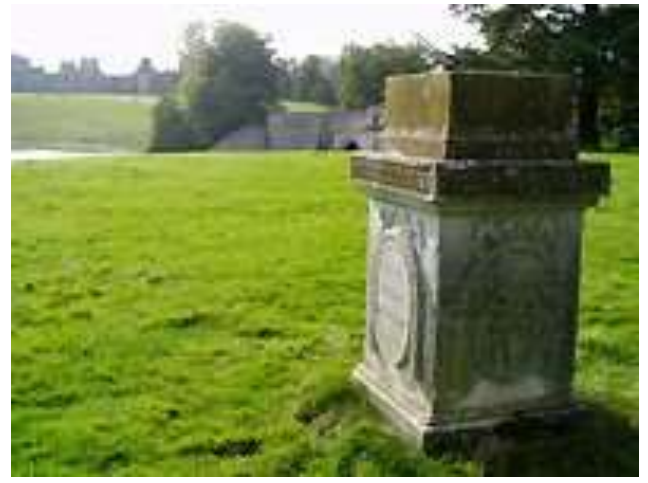

Рис. 2. Пам'ятний знак на місиі зруйнованого замку Вудсток. (Рipe S., 2007)

Та все ж приходить розуміння цінності історичних архітектурних об'єктів починається історія становлення наукової реставрації та формування іï методології. У XVIII столітті на зміну уявленням про минуле приходить розуміння важливості знання достовірної інформації про події та пам'ятки. Йоганн-Йоахім Вінкельман (Johann Joachim Winckelmann, 1717 - 1768), німецький мистецтвознавець, спробував ввести в реставрацію наукову методику, основою якої мало бути ретельне вивчення пам'ятки, в тому числі залучання історичних документів, ії порівняльне співставлення з іншими пам'ятками даного типу. Його учнем був Рафаель Стерн (Raffaele Stern,1774-1820), італійський архітектор, що проводив реставрацію Колізею. Роботи велися способом «спроб та помилок». Зовнішнє кільце стін амфітеатру, яке було частково втрачене, укріпили добудовою двох контрфорсів. По один бік спорудили глухий контрфорс, що виглядав як скошена стіна. Зрозумівши, що «підпора» дисонує з пам'яткою, контрфорс з іншого боку споруджувався, відтворюючи втрачені фрагменти стін та їх декорації. Паралельно слід згадати Джузеппе Валадьє (Giuseppe Valadier, 1762-1839) та його реставрацію арки Тита 1821 р. Його втручання в автентичну структуру пам'ятки виділяється двома позиціями: доповнення виконані із травертину, сама споруда побудована із мармуру, а також спрощено відтворений декор (Подьяпольский, 2000). Колізей також мав відмінності у матеріалах: автентична споруда - травертин, доповнення - цегла. Дана візуальна різниця між оригіналом і сучасним втручанням була першим кроком на шляху до становлення сучасних мірок фаховості реставраційного втручання. Проте ії регламентують аж через півтора століття. Реставраційна діяльність починається з пам'яток античного періоду в XIX ст. Представлені приклади є саме тою реставрацією, яку ми підтримуємо сьогодні, проте у реставраторів були різні бачення прекрасного.

Пам'ятки почали відновлювати, застосовуючи метод аналогій, і трендом у збереженні архітектурних об'єктів стали стилістичні реставрації. Метою постає відтворення первісного вигляду споруди, його цілісна реставрація. Говорячи про стилістичні реставрації, прикладом постає замок П'єрфон (Chateau de Pierrefonds, France), що два століття перебував у стані руїни, а в другій половині XIX ст. постає проектом відбудови Ежена Віолле-ле-Дюка (Eugène Emmanuel Viollet-le-Duc 1814-1879), французького історика та теоретика архітектури, реставратора. Йому належать слова: «Реставрувати будівлю не означає

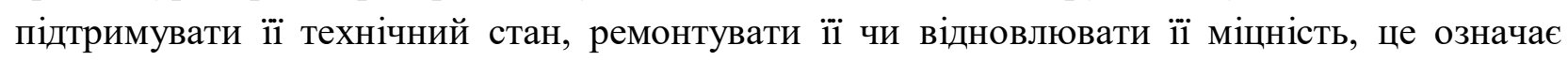


відбудовувати ії в завершеному вигляді, який, можливо, ніколи раніше не існував» (Віоллеле-Дюк, 1937). Він вважав, що будівля має бути завершеною і не будував гіпотез стосовно того, як замок міг би виглядати раніше: минуле було втрачене, а знання про нього - відсутні. Віолле-ле-Дюк став співавтором невідомого архітектора, що керував будівництвом первісного замку п’ять століть до нього. Незважаючи на гучну критику, стилістичні реставрації поширилися Європою.

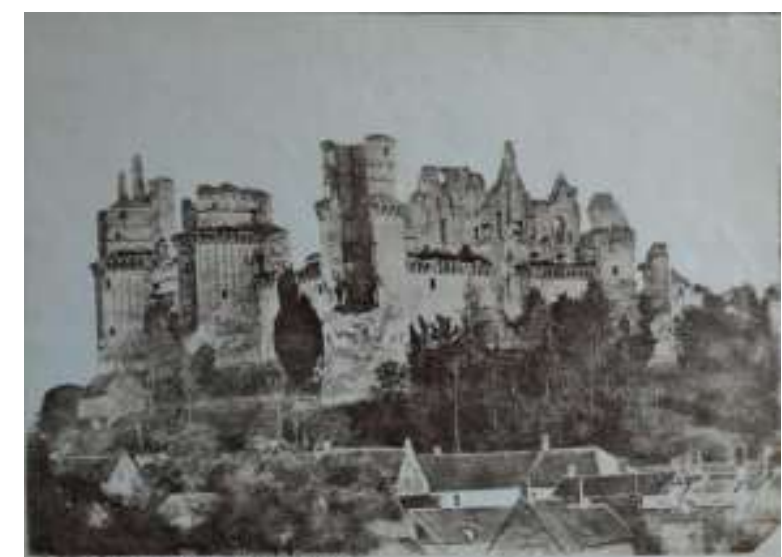

Рис.3. Замок П'єрфон до реставрації, архівне фomo, 1870 p. (Galerie Michel Cabotse, 2009)

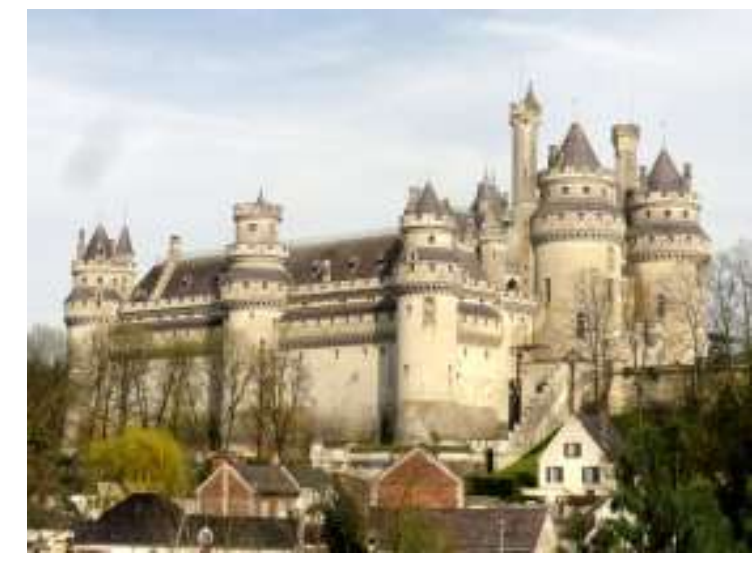

Рис.4. Замок П'єрфон, фото, 2013 р. (Arzamas, 2020)

Західноєвропейська культурна атмосфера вплинула і на реставраційну діяльність на території України. Прихильником даної неоромантичної концепції реставрацій був архітектор та реставратор Юліан Захаревич (1837-1919рр.). У 1882 році він входив до складу комісії, яка визнала Олеський замок, що на той час перебував в стані руїни, придатним до реставрації. Ю. Захаревич разом із Л. Вєжбицьким розробляли проект реставрації замку. Проте роботи на об'єкті обмежилися лише його виведенням з аварійного стану, подальші реставраційні роботи проводилися 1933 р. під керівництвом В. Мінкевича, далі після Другої світової війни розробкою проекту пристосування замку під музей займалися Львівські реставраційні майстерні під керівництвом І. Могитича. Роботи 3 реставрації інтер'єрів тривали до 1975 року, після чого замок був відкритий для відвідувачів (Бевз, 2018). Останнім керівником реставраційних робіт на замку був Б. Возницький. Як результат, замку було повернуто вигляд на період його найбільшого розквіту - кінця XVIII ст. Реставрація, яка почалася у кінці XIX ст., не зважаючи на розтягнутість у часі, все ж завершилася повною відбудовою об’єкта.

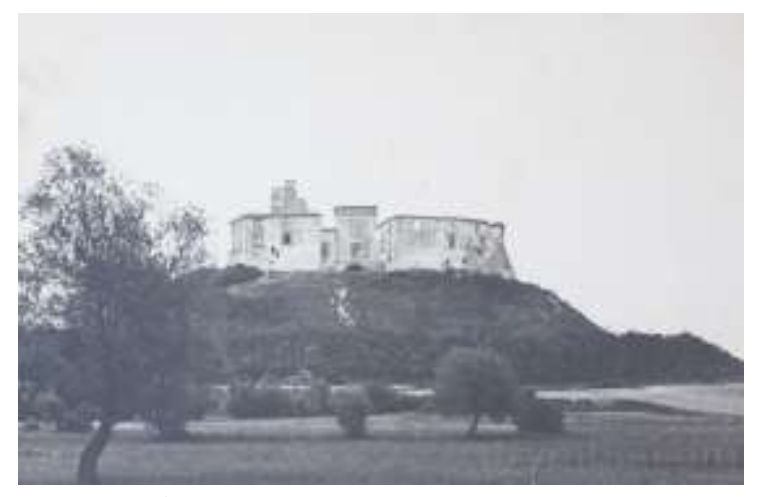

Рис.5. Олеський замок в стані руїни, архівне фото, 1950-mi p. (Andrij, 2018)

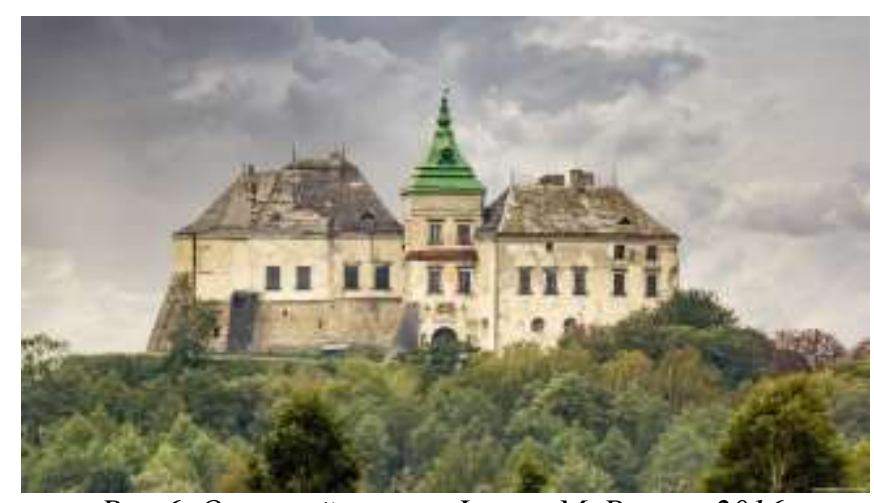

Рис.6. Олеський замок. Фото: М. Ритус, 2016. (M_A_D_M_A_X, 2016)

Стилістичні реставрації, результатом яких ставала ідеальна картинка, до кінця XIX ст. спричинили до появи кардинально протилежних методів реставрації - археологічних. Камілло Бойто (Camillo Boito, 1836-1914), італійський архітектор та мистецтвознавець, 
обурювався ідеями стилістичних реставрацій, оскільки вони стирали грань між старим і новим. Він зазначав необхідність впровадження стилістичних та технічних відмінностей в процесі реставрації між існуючими та нововведеними частинами пам'ятки, включення яких мало ретельно документуватися. Йому належить і перша класифікація реставрації, яку він поділив відповідно до епох становлення пам'яток: археологічна, художня та архітектурна. Власне художня реставрація пропонувалася для середньовічних замків, для об'єктів, які мали найрізноманітніші композиційні та декоративні рішення. Тут він відзначав неможливість відтворення будь-яких частин чи елементів споруди, якщо їх сліди та фрагменти були втрачені. Наголошував на цінності всіх історичних нашарувань пам'яток, які нівелювали реставратори-стилісти, стараючись досягти «чистоти стилю». Його погляди лягли в основу «Великої хартії» (Prima Carta del Restauro) італійських реставраторів 1883 року.

Своє бачення в класифікації пам'яток пропонував і італійський архітектор та консерватор Густаво Джованноні (Gustavo Giovannoni, 1873-1947), поділяючи пам'ятки на «живі» та «мертві», тобто ті, які можливо пристосувати до сучасних потреб, і ті, які вже нездатні виконувати утилітарну функцію. Тобто замки, які перебували у стані руїни, повинні були залишатися руїнами і могли фігурувати лише як пам’ятки історії та культури.

При цім слід враховувати, що ХІХ ст. було періодом романтизму - в замкових руїнах вбачали мальовничість, тож цілком природно в широке застосування входить метод консервації, що і лежав в основі археологічних реставрацій.

Гайдельбергський замок (Heidelberger Schloss, Deutschland) класифікується як руїна після воєнних дій в кінці XVII ст. Безуспішними були як спроби його відбудови, так і ідеї розібрати на будматеріал. Тут і були втілені ідеї археологічної реставрації. В кінці ХІХ ст. розроблено проект, який передбачав консервацію замкових руїн. Реставрацію було передбачено лише на споруді, яка була понищена пожежею, але не зруйнованою. У комісію, що визначила долю збереження замку як руїни, входив Вільгельм Любке (Wilhelm MeyerLübke, 1861-1936), який висловлювався: «Наша спрага відновлення досягла небезпечної точки. Це стало лихоманкою, яка у своєму шаленстві ось-ось знищить розкішні пам'ятки наших предків» (Lübke, 1861). Лихоманку почали лікувати - на перше місце виходить ідея недоторканності пам'ятки, а Гайдельбергський замок сьогодні гордо носить звання найбільших руїн в Німеччині.

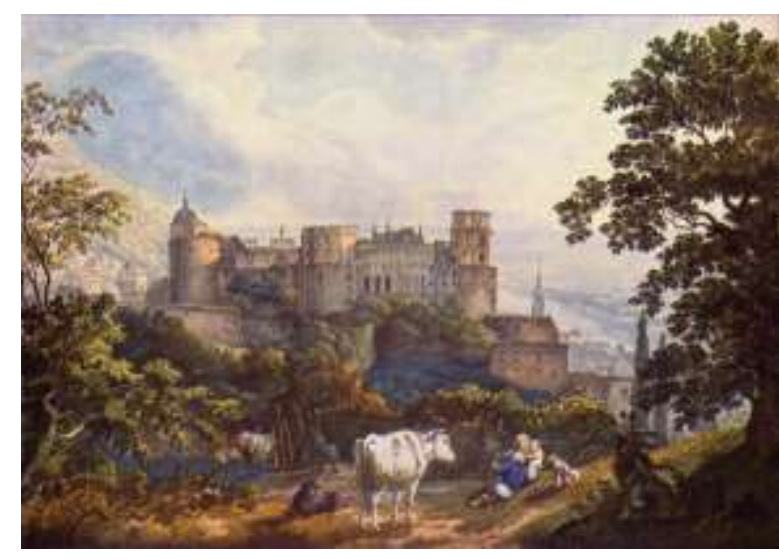

Рис.7. Гайдельбергський замок. Karl Philipp Fohr, полотно, олія, 1815p. (The Yorck Project, 2002)

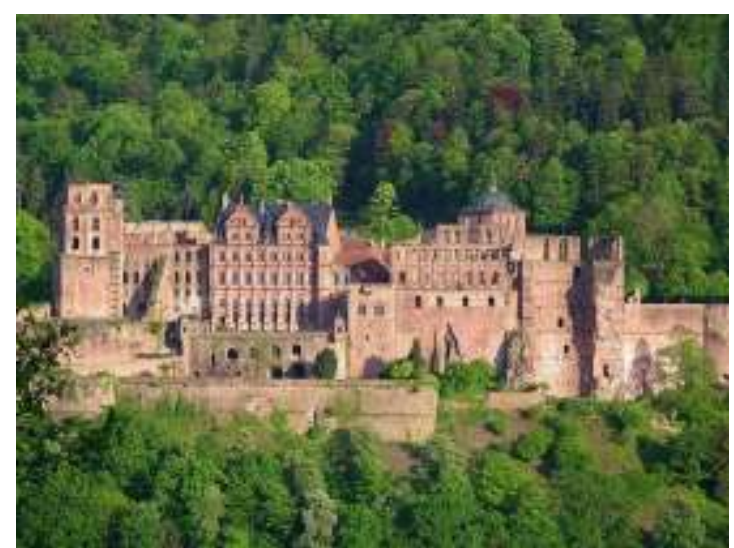

Рис.8. Гайдельбергський замок станом на 2005 p. Фomo: Reinhard Wolf.

(Wolf, 2005)

Полеміки між прихильниками стилістичної та археологічної реставрації тривали роками - вони вбачали цінність у різних субстанціях пам'ятки. Прибічники археологічної реставрації вболівали за матеріальну структуру пам'ятки, стилісти ж вбачали красу у 
завершеному образі споруди. Важливий крок у розвиток теорії реставрації зробив австрійський історик та мистецтвознавець Алоїз Рігль (Alois Riegl, 1858-1905). Він стверджував, що будь-яка пам'ятка представляє собою дві цінності - історичну та сучасну. Історичну цінність представляли значення об'єкта та його стан, тобто, чим цілісніший оригінал - тим вища історична цінність. Окремо виділяв «цінність давнини», що вимагала від реставратора відкидати ідеї доповнень щодо пам'ятки, а також зберігати історичні нашарування, так звану «патини часу». Сучасну цінність являли собою експлуатаційні та художні якості об'єкта, які є відносними і залежать від смаків та потреб сучасного суспільства (Ригль, 2018).

1931 року був сформований перший міжнародний документ, що регламентував охоронно-реставраційні заходи на пам'ятках, - Афінська хартія. На перше місце виводяться принципи археологічної реставрації - збереження пам'ятки без будь-яких змін і доповнень. На основі Афінської хартії в 1964 році було сформовано Венеціанську хартію, метою котрої постали «охорона й реставрація нерухомих історичних пам'яток, спрямовані на збереження їх не лише як творів мистецтва, а й як свідків історії» (Міжнародна хартія, 1964).

Та історія вносить свої корективи: друга половина ХХ ст. після великих втрат під час Другої світової війни спричинила повернення до теми цілісної відбудови, проте на науково обгрунтованих засадах. Повна відбудова замкової руїни у ХХ ст., що була визнана науковою спільнотою та внесена до Переліку Всесвітньої культурної спадщини ЮНЕСКО, належить руці реставратора Яна Захватовича (Jan Zachwatowicz, 1900-1983). Бомбардування 1944 р. зрівняли Королівський замок у Варшаві (Zamek Królewski w Warszawie, Polska) із землею (Рис.9). Ян Захватович стверджував: «Не маючи змоги погодитися зі знищенням наших пам'яток культури, будемо їх реставрувати, будемо відбудовувати їх від підмурків, щоб передати нащадкам якщо не автентичну, то хоча б точну форму їх, живу у нашій пам’яті і приступну в матеріалах [...] Звичайно, в шляхетній реставраційній науці це є кроком назад на кілька десятків років, однак на нашому грунті є єдиним можливим шляхом розвитку» (Zachwatowicz, 1946). Замок, який ми спостерігаємо сьогодні у центрі Варшави, є новою спорудою, збудованою в період 1971-1984 років. Маючи всі необхідні дані про вигляд втраченого об'єкта, вдалося відтворити його точну копію.

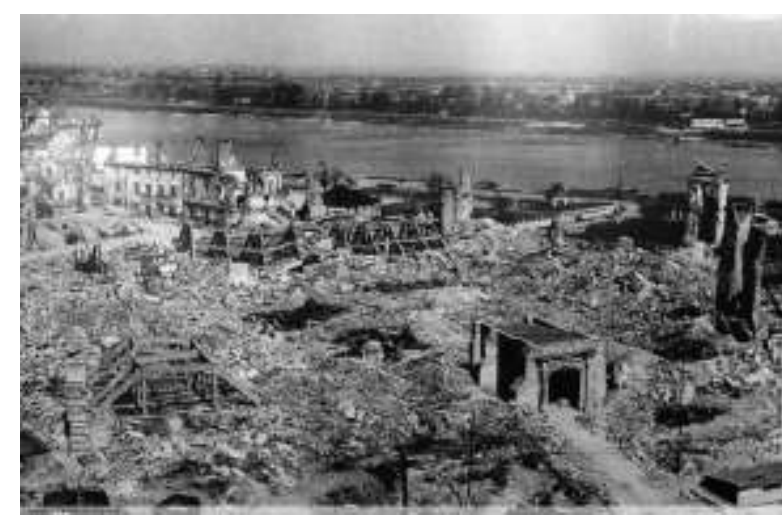

Рис.9. Руїни Королівського замку у Варшаві після бомбардування 1944p., архівне фото, 1947p. (Polska-org, 2018)

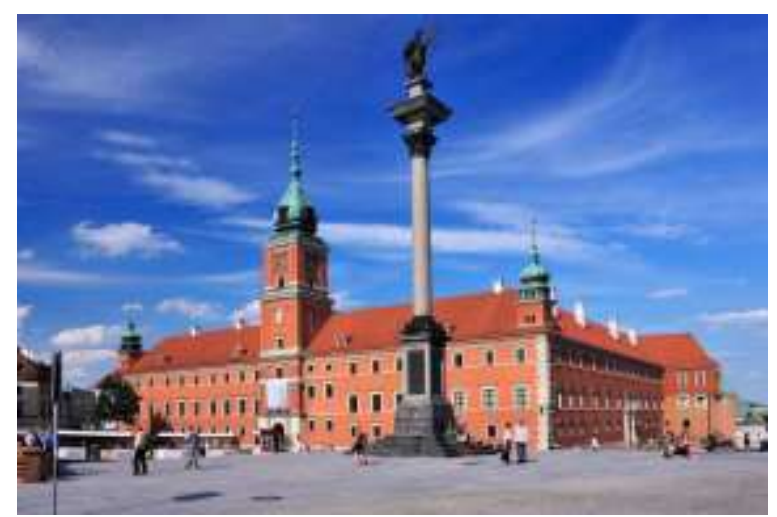

Рис. 10. Королівський замок у Варшаві у ХХI cm. Фomo: Zbigniew Panow. (Warsawtour, 2020)

Зруйновані пам'ятки архітектури знову накриває хвиля відбудов. Для прикладу розглянемо змок у місті Тракай (Traku salos pilis, Lietuva). Початок його будівництва припадає на кінець XIV ст., та вже з XVII ст. починає занепадати та перетворюється в руїну. В 1888 р. були проведені обміри та зафіксовано стан споруди. Царський уряд дав команду 
підтримувати руїни та провести часткову відбудову, про повну реконструкцію мови не йшлося, оскільки іконографічні матеріали про вигляд замку були відсутні. Проте, коли у 1960-1970 роках виділили фінансування, Тракайський замок відбудували у повному об'ємі. Рішення про відбудову було аргументовано значенням замку для держави та нації, бажанням зберегти реліквії та відновити хоча б один із середньовічних замків Литви, створивши його образ, «яким би він міг бути» (Riaubiene, 2012). В даному випадку мала вплив загальна тенденція до відбудови в післявоєнний період, коли велика кількість пам'яток була втрачена.

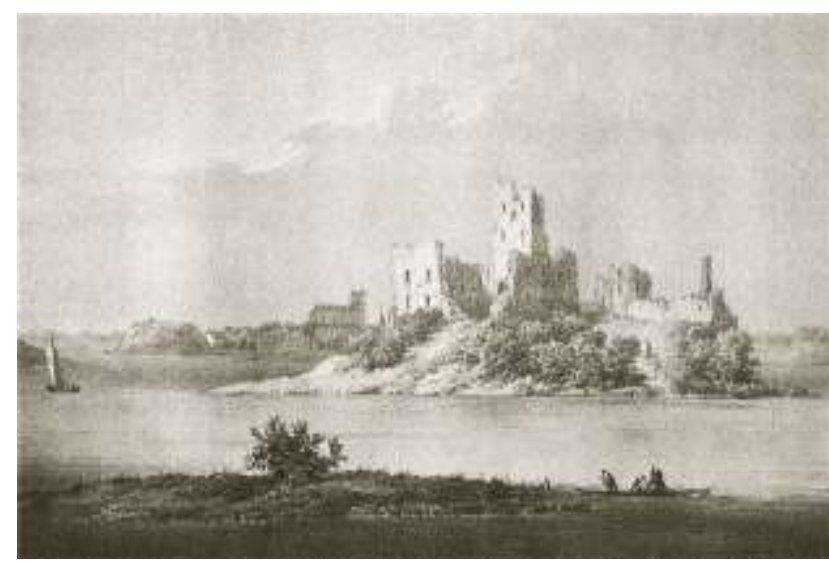

Рис.11. Тракайський замок в стані руїни. Наполеон Орда, літографія, 1883 р. (Orda, 1883)

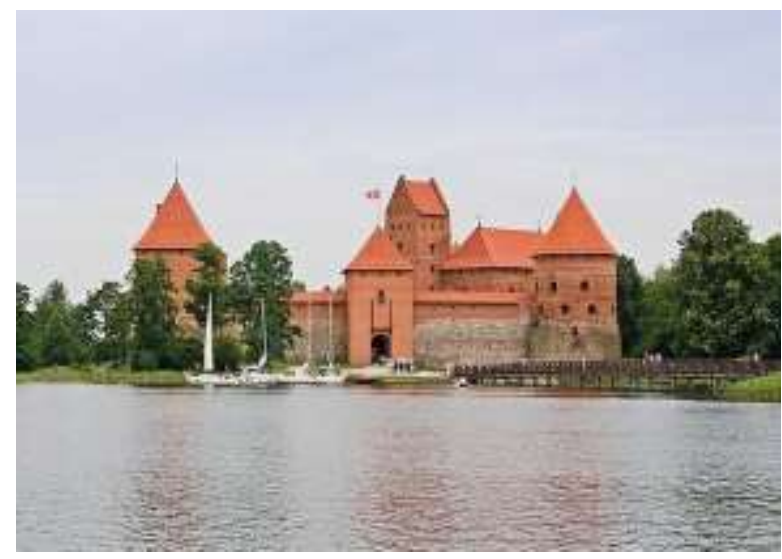

Рис. 12. Тракайський замок. Фomo, Dmitry Mottl, 2008. (Mottl, 2008)

Верхній замок у Вільнюсі (Vilniaus Aukštutine pilis, Lietuva) мав всі шанси повторити долю Тракайського. 3 XVI ст. через втрату оборонної функції, як і в більшості литовських замків, припиняють підтримувати належний технічний стан споруди. У XVIII ст. в замку почалися руйнівні процеси, спричинені в тому числі і руйнуванням гори Гедиміни, на якій він розташовувався. У XIX ст. була проведена консервація автентичної кладки та відбудована одна з веж, яку адаптували під музей. За рахунок розташування на узвишші зі складною геологічною структурою, він уникнув у XX ст. повної відбудови. Сьогодні і далі ведуться дискусії, чи повинен замок бути збережений у вигляді руїни, чи його таки слід відбудувати у легких конструкціях, щоб реконструювати силует міста (Povilaityte, 2016).

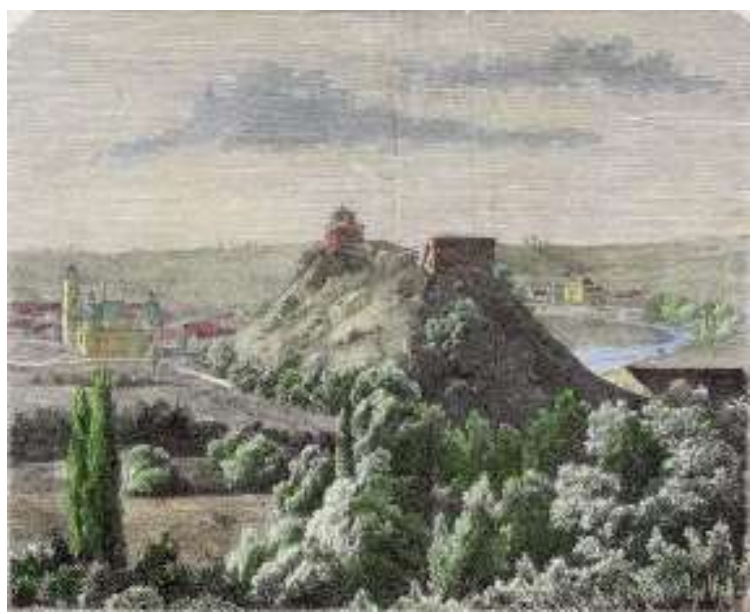

Pис.13. Вид на верхній замок у Вільнюсі. Julian Ceglinski, ксилографiя, 1861p. (Tygodnik Ilustrowany, 1861)

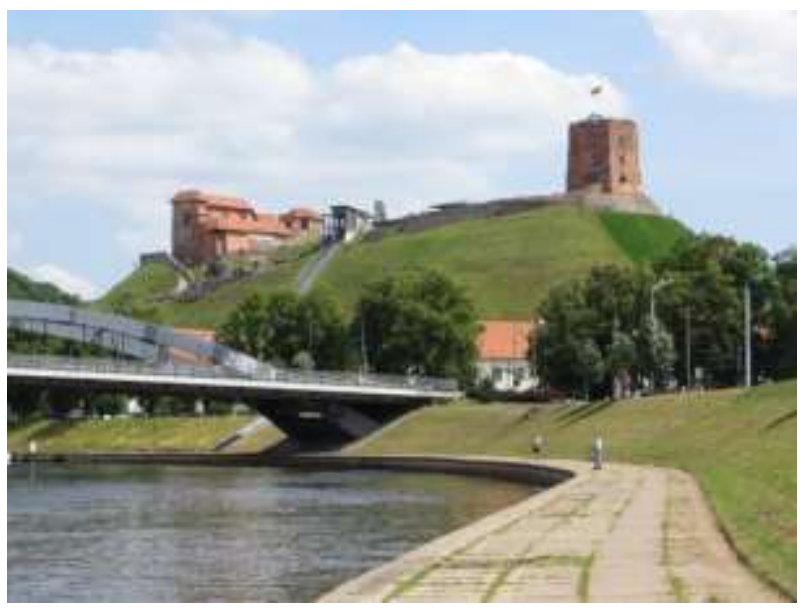

Pис.14. Вид на верхній замок у Вільнюсі. Фomo: Bernt Rostad, 2013 p. (Rostad, 2013) 
Все ж об’єкт в руїні як кінцевий результат реставраційного втручання посідає своє законне місце. Цікавим прикладом є реставрація замку у містечку Іновлодзь (zamek $w$ Inowłodzu, Polska), який занепадає з середини XVII ст. та розбирається на будматеріал. В XIX ст. ще збережені фрагменти замкових мурів практично зрівнялися із землею. В 1970-их роках розпочалися археологічні розкопки, руїни законсервували. В період 2011-12 років замок був частково відбудований, проте залишений у стані руїни: втручання було доти, доки достовірно знали попередній вигляд. В результаті замок став центром культурного життя містечка та поштовхом до його розвитку. Замкова руїна наповнилася центром для відвідувачів, невеличкою бібліотекою та приміщенням для проведення навчань і конференцій. Послугами замку користуються як туристи так і місцеві мешканці, є доступ i для людей з обмеженими можливостями (Latosinska, 2015).

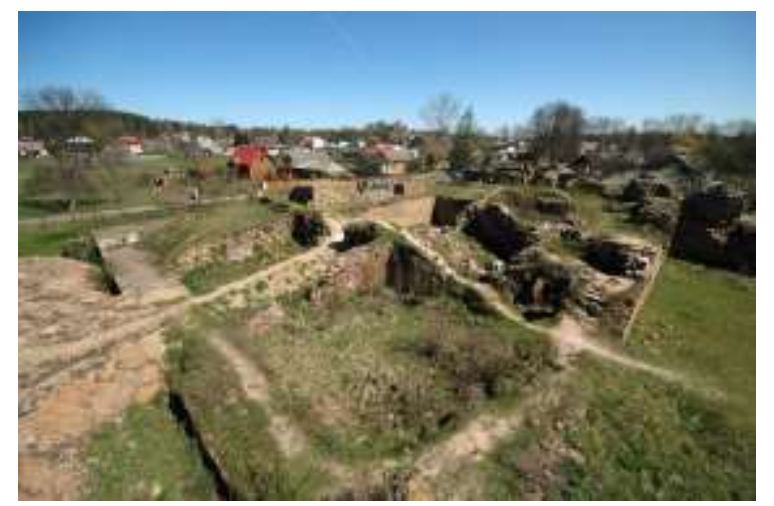

Рис.15. Замок в Іновлодзю до реставрації Фomo: ZeroJeden, 2007. (Polskie zamki, 2007)

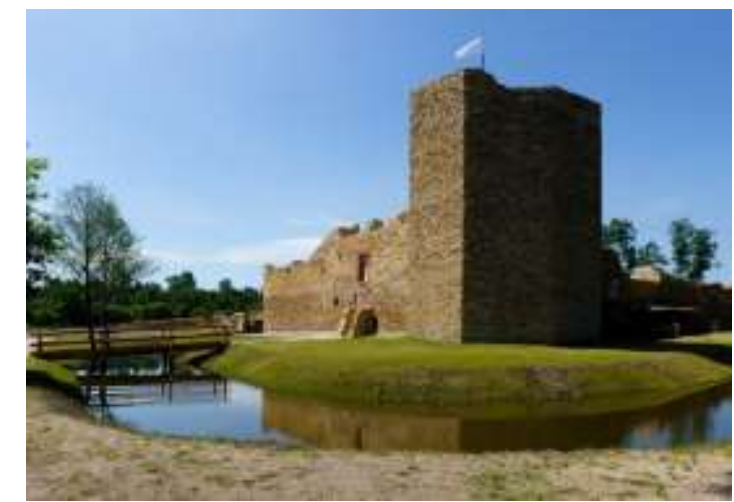

Рис.16. Замок в Іновлодзю.

Фomo: Yacek Bednarek, 2013. (Bednarek, 2013)

На представлених прикладах спостерігаємо, що ряд хартій, які рекомендували обмежувати втручання в матеріальну структуру архітектурних пам'яток, не працювали як годиться. Суспільство надає перевагу завершеним об'єктам, які є для них зрозумілими. Тож у 2000 році ухвалили Ризьку хартію, що допускала реконструкцію на пам'ятках, проте регламентувала ii, ставивши основний наголос на чіткій відмінності доповнюючих матеріалів від автентичних.

XXI століття розкрило замкову руїну в новому світлі. Консерваційну діяльність почали поєднувати з впровадженням відверто нових матеріалів, таких як скло та метал. Тож ряд руїн отримав нове обличчя без зайвого втручання в автентичну структуру (Гаврилів, 2020). На території України таким прикладом став Острозький замок, а саме одна з його веж під назвою Татарська. Занепад споруди почався з другої половини XVII ст., у 1913 та 1960их роках вежу реставрували, та все ж донедавна вона була руїною, поглинутою зарослями та біонаростами. 2018 року зруйновану частину стіни Татарської вежі відтворили за допомогою металевої конструкції, що включала браму, бійниці та аттик. Слід зазначити, що конструкція $€$ автономною і не втручається в автентичну структуру пам'ятки. Реконструкція стіни $€$ мистецькою інсталяцією під назвою «Культурний Барбакан», яка мала не меті не лише врятувати пам'ятку архітектури від руйнування, але і популяризувати історію міста, облаштувати простір для проведення різноманітних заходів та загалом зацікавити туриста. Вона стала об'єктом сучасного монументального мистецтва. 


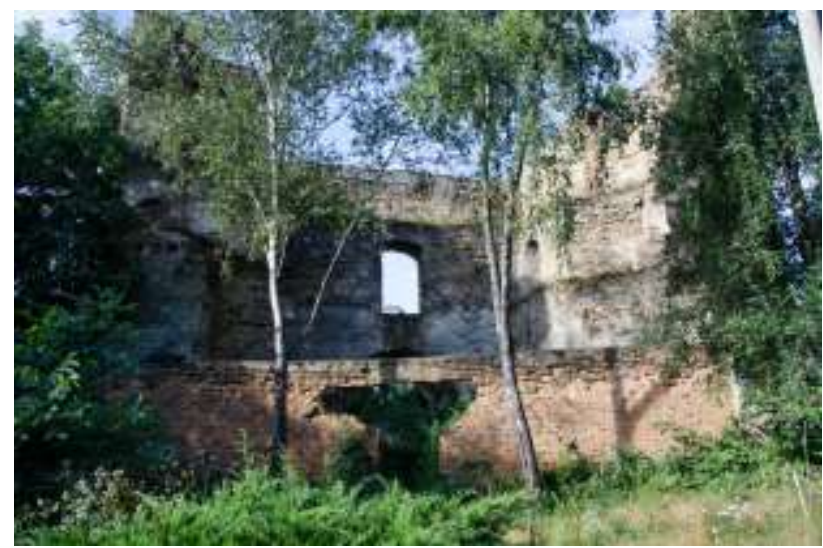

Рис.17. Татарська вежа, фото, 2017.

(Державний історико-культурний заповідник міста Острога, 2017)

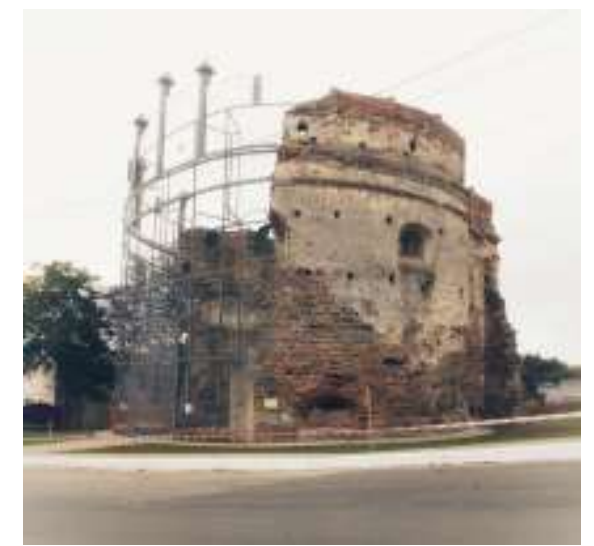

Рис.18. Арт-простір «Культурний Барбакан» (Рівне 1, 2018)

\section{Узагальнення результатів аналізу}

Вважається, що реставраційна діяльність, яка проводилася в період стилістичних реставрацій, мала негативне значення для «реставрованих пам'яток», але саме тоді запроваджується глибоке натурне дослідження пам'ятки. Можна охарактеризувати дану діяльність як «псевдореставрація», тобто те, що передувало реставрації, яка стала «лікарством» для покинутих та забутих об’єктів культурної спадщини.

3 початком розуміння цінності матеріальної структури пам'ятки - іï автентичної складової, - у ХХ ст. суспільство знову звертається до методу відбудови. Професор А. Грушецький стверджував: «Нам, реставраторам, тільки здається, що ми розумні, втаємничені, що ми визначаємо шлях реставрації пам'яток. Насправді ж ми залишаємося тільки на послугах у суспільства i, самі того не усвідомлюючи, так керуємо реставрацією, як воно вимагає... Не реставратори нав'язали відбудову Старого Мяста суспільству, а навпаки, суспільство нав'язало іï реставраторам" (Gruszecki, 1984). Звідси випливає, що багато залежить від замовника, від того, хто фінансує реставраційну діяльність: який метод застосовуватиметься - відбудова, консервація, реставрація. Завданням реставратора $\epsilon$ скоригувати дане рішення і правильно втілити задум в життя.

Реставраційна діяльність розвивається як живий організм. XXI століття характеризуються впровадженням в законсервовану автентичну пам'ятку відверто сучасних матеріалів (метал, скло), спричиняє до дуже цінного ефекту - тепер не лише науковець бачить чітку різницю між автентичною і нововведеною матерією, але i пересічний відвідувач. I цей пересічний відвідувач теж починає розуміти цінність старовини і насолоджуватися нею.

\section{Висновки}

Реставрація саме замкової руїни спричинила дискурс щодо способу збереження пам'яток архітектури, адже замок, враховуючи конструкцію, розташування та функцію, $є$ одним із найскладніших видів споруд.

Впродовж століть із врахуванням історичних передумов, розвитку суспільної свідомості, зміни архітектурних стилів та появи на ринку нових будівельних матеріалів трактування поняття реставрації, іiї завдань та цінності для збереження культурної спадщини для суспільства постійно змінювалося. Останні пів тисячоліття - епоха системних експериментів над культурною спадщиною Європи 3 діаметрально протилежними рішеннями, досвідом та результатами. В будь-якому випадку залишалася обов'язковою 
вимога, аби об’єкт діяв та був відвідуваним, незалежно від того, чи був він композиційно завершеним, чи фрагментарно збереженим.

Відтак приходимо до вискову, що в XXI столітті та українських реаліях замок в стані тривалої руїни в першу чергу повинен підлягати консервації, а враховуючи незнання його оригінального вигляду та фінансові труднощі, - метод повної відбудови повинен бути відкинутий. Головний майбутній користувач замку - турист, тож головна мета реставраційних робіт сьогодні - зробити об’єкт доступним та відкритим для відвідування.

\section{Використана література та джерела}

Бевз М. В., 2004. Методологічні основи збереження та регенерачії заповідних архітектурних комплексів історичних міст (на прикладі Західної України): дис. докт. арх. наук. Харківський державний технічний будівництва та архітектури.

Бевз.М., 2018. Реставрація пам'яток архітектури на Львівщині у ХХ ст. на тлі розвитку реставрачійних поглядів у Галичині. Матеріали конференції / Materials. c. 22-29.

Бобров Ю., 2004. Теория реставраџии памятников искусства: закономерности и противоречия. Дис. док.арх.

Виолле-ле-Дюк Э., 1937. Беседы об архитектуре. Переклад з мови А.А. Сапожникова. Москва: Издательство всесоюзной академии архитектуры.

Гаврилів К. М., 2020. Ревіталізація замкових руїн: європейський досвід. Current issue in research, conservation and restoration of historic fortification, 12. Chelm - Lviv. c. 73-85.

Державний історико-культурний заповідник міста Острога, 2017. Татарська вежа. [online] Доступно: <https://ostrohcastle.com.ua/tatarska-vezha/> [Дата звернення: 1 лютого 2021].

Лесик О., 2013. Принциии реставрації пам'яток архітектури. Традииії і новаторство. Українська академія мистецтва, 21. с. 97-103.

Міжнародна хартія з охорони й реставрації нерухомих пам'яток $і$ визначних місиь (Венеиіанська хартія), 1964.

Пламеницька О. А., 1999. Ян Захватович. Слава і недоля майстра. Пам'ятки України. Історія та культура, 1. с. 122-131.

Подьяпольский С.С., Бессонов Г. Б., Беляев Л. А., Коркин В.Д., Постникова Т.М., Табунщиков Ю.А., 2000. Реставрация памятников архитектуры. Москва: Стройиздат.

Прибєга Л., 2015. Архітектурна спадщина Украӥни. Пам'яткоохоронний аспект. Київ: Інститут культурології НАМ України.

Ригль А., 2018. Современный культ памятников: его сущңность и возникновение. Москва: ЦЭМ, V-A-C press.

Рівне 1, 2018. Рівненщина містична: друге життя Татарської вежі. [online] Доступно: <https://rivne1.tv/news/95940> [Дата звернення: 1 лютого 2021].

Трегубова Т., 1994. Відтворення втрачених пам'яток. Історичний та правовий аспект. Пам'ятки України. Історія та культура, 3. с. 135-136.

Andrij, 2018. Музей-заповідник Олеський замок (с.м.т. Олесько, Львівська обл.): карта, фото, опис (Замок Даниловичів). [online] Доступно: <https://drymba.com/uk/1033515-oleskyyzamok-olesko> [Дата звернення: 1 лютого 2021].

Arzamas, 2020. Как оставлять старое старым. [online] Доступно: $<$ https://arzamas.academy/materials/487> [Дата звернення: 1 лютого 2021].

Bednarek J., 2013. Inowlodz. Ruina zamku Krolewskiego. [online] Доступно: $<$ https://www.zamkipolskie.com/inowlodz/inowlodz.html> [Дата звернення: 2 лютого 2021].

Galerie Michel Cabotse, 2009. Chateau de Pierrefonds, ruines avant restauration. [online] Доступно: 
<http://webcache.googleusercontent.com/search?q=cache:http://www.michelcabotse.com/_Catalo gue/Fiche/art-0-2983154.htm?Categorie=Photographie $>$ [Дата звернення: 26 січня 2021].

Gruszecki A., 1984. Wspomnienie o profesorze Zachwatowiczu - konserwatorze zabytków. Ochrona zabytków, 2. - s. 86.

Jokilehto J., 1986. A History of Architectural Conservation. The University of York, England.

Latosinska J., Wlodarczyk B., 2015. Badania nad turystyczno-kulturalnym wykorzystaniem zamku w Inowłodzu w pierwszym roku po rekonstrukcji. Warsztaty z Geografii Turyzmu. s. 75-99.

Lübke W., 1861. Das Restaurationsfieber.

M_A_D_M_A_X, 2016. Наследие. Олеско. Монастырь капуциинов + замок/Спадщзина. Олесько. Монастир капуцинів + замок. Part 1. [online] Доступно: <https://m-a-d-m-ax.livejournal.com/363204.html> [Дата звернення: 1 лютого 2021].

Mottl D., 2008. Trakai Island Castle. [online] Доступно: <https://commons.wikimedia.org/wiki/File:Trakai_Island_Castle.jpg> [ Дата звернення: 2 лютого 2021].

Orda N., 1883. Trakai Island Castle in 19c. [online] Доступно: <https://commons.wikimedia.org/wiki/File:Trakai_Island_Castle_in_19c.jpg> [Дата звернення: 2 лютого 2021].

Pipe S., 2007. Woodstock's lost royal palace. [online] Доступно: $<$ http://www.bbc.co.uk/oxford/content/articles/2007/10/17/glyme_feature.shtml> [Дата звернення: 1 лютого 2021].

Polska-org, 2018. Zamek Królewski w Warszawie w 1947 roku. [online] Доступно: <https://polska-org.pl/7144465, foto.html?idEntity=7118296> [Дата звернення: 20 січня 2021].

Polskie zamki, 2007. Zamek $w$ Inowlodzu. [online] Доступно: <http://www.zamki.pl/?idzamku=inowlodz\&msg=0> [Дата звернення: 2 лютого 2021].

Povilaityte E., 2016. The Conservation History, Problems and the Rehabilitatiom of Lithuanian Medival Castles. Procedia - Social and Behavioral Sciences, 225. s. 85-95.

Riaubiene E., 2012. Use of Architectural Heritage: Challenhes of Preservation and Adaptation. Architecture and Urban Planning, 6. s. 25-30.

Rostad B., 2013. Upper Castle in Vilnius. [online] Доступно: <https://www.flickr.com/photos/brostad/9651317009/> [Дата звернення: 2 лютого 2021].

Ruskin J., 1849. The semen Lamps of architektura. London.

The Yorck Project, 2002. Heidelberg Castle. [online] Доступно: <https://commons.wikimedia.org/wiki/File:Carl_Philipp_Fohr_001.jpg> [Дата звернення: 1 лютого 2021].

Tygodnik Ilustrowany, 1861. Vilnius Upper Castle, Lithuania. [online] Доступно: <https://commons.wikimedia.org/wiki/File:View_of_Vilnius_Upper_Castle_with_remaining_Ged iminas_Tower.jpg> [Дата звернення: 2 лютого 2021].

Warsawtour, 2020. Zamek Królewski w Warszawie. [online] Доступно: <https://warsawtour.pl/zamek-krolewski-w-warszawie-3/> [Дата звернення: 20 січня 2021].

Wolf R., 2005. Heidelberger Schloß, Gesamtansicht von NNW. [online] Доступно: <https://commons.wikimedia.org/wiki/File:Heidelberg-Schlo\%C3\%9F.JPG> [Дата звернення: 2 лютого 2021].

Zachwatowicz Jan., 1946. Program i zasady konserwacji zabytków. Biułetyn Historii Sztuki I Kultury, 1-2.

\section{References}

Bevz M.V., 2004. Metodolohichni osnovy zberezhennya ta reheneratsiyi zapovidnykh arkhitekturnykh kompleksiv istorychnykh mist (na prykladi Zakhidnoyi Ukrayiny). Dys. dokt. arkh. nauk. Kharkivs'kyy derzhavnyy tekhnichnyy budivnytstva ta arkhitektury. 
Bevz M.V., 2018. Restavratsiya pam'yatok arkhitektury na L'vivshchyni u KHKH st. na tli rozvytku restavratsiynykh pohlyadiv u Halychyni. Materialy konferentsiyi / Materials. s. 22-29.

Bobrov Y.U., 2004. Teoriya restavratsii pamyatnikov iskusstva: zakonomernosti $i$ protivorechiya. Dis. dok. arkh.

Violle-le-Dyuk E., 1937. Besedy ob arkhitekture. Pereklad z movy A.A. Sapozhnikova. Moskva: Izdatel'stvo vsesoyuznoy akademii arkhitektury.

Havryliv K.M., 2020. Revitalizatsiya zamkovykh ruyin: yevropeys'kyy dosvid. Current issue in research, conservation and restoration of historic fortification, 12. Chelm - Lviv. s. 73-85.

Derzhavnyy istoryko-kul'turnyy zapovidnyk mista Ostroha, 2017. Tatars'ka vezha. [online] Available at: <https://ostrohcastle.com.ua/tatarska-vezha/> [Date of reference: 1 February 2021].

Lesyk O., 2013. Pryntsypy restavratsiyi pam'yatok arkhitektury. Tradytsiyi $i$ novatorstvo. Ukrayins'ka akademiya mystetstva, 21. s. 97-103.

Міжнародна хартія з охорони й реставрації нерухомих пам'яток $і$ визначних місиьь (Венеціанська хартія), 1964.

Plamenyts'ka O. A., 1999. Yan Zakhvatovych. Slava i nedolya maystra. Pam'yatky Ukrayiny. Istoriya ta kul'tura, 1. s. 122-131.

Pod'yapol'skiy S.S., Bessonov G.B., Belyayev L.A., Korkin V.D., Postnikova T.M., Tabunshchikov Y.A., 2000. Restavratsiya pamyatnikov arkhitektury. Moskva: Stroyizdat.

Prybyeha L., 2015. Arkhitekturna spadshchyna Ukrayiny. Pam'yatkookhoronnyy aspekt. Kyyiv: Instytut kul'turolohiyi NAM Ukrayiny.

Rigl' A., 2018. Sovremennyy kul't pamyatnikov: yego sushchnost' $i$ vozniknoveniye. Moskva: TSEM, V-A-C press.

Rivne 1, 2018. Rivnenshchyna mistychna: druhe zhyttya Tatars'koyi vezhi. [online] Available at: <https://rivne1.tv/news/95940> [Date of reference: 1 February 2021].

Trehubova T., 1994. Vidtvorennya vtrachenykh pam'yatok. Istorychnyy ta pravovyy aspekt. Pam'yatky Ukrayiny. Istoriya ta kul'tura, 3. s. 135-136.

Andrij, 2018. Muzey-zapovidnyk Oles'kyy zamok (s.m.t. Oles'ko, L'vivs'ka obl.): karta, foto, opys (Zamok Danylovychiv). [online] Available at: <https://drymba.com/uk/1033515-oleskyy-zamokolesko> [Date of reference: 1 February 2021].

Arzamas, 2020. Kak ostavlyat staroye starym. [online] Available at: <https://arzamas.academy/materials/487> [Date of reference: 1 February 2021].

Bednarek J., 2013. Inowlodz. Ruina zamku Krolewskiego. [online] Available at: <https://www.zamkipolskie.com/inowlodz/inowlodz.html> [Date of reference: 2 February 2021].

Galerie Michel Cabotse, 2009. Chateau de Pierrefonds, ruines avant restauration. [online] Available at:

<http://webcache.googleusercontent.com/search?q=cache:http://www.michelcabotse.com/_Catalo gue/Fiche/art-0-2983154.htm?Categorie=Photographie $>$ [Date of reference: 26 January 2021].

Gruszecki A., 1984. Wspomnienie o profesorze Zachwatowiczu - konserwatorze zabytków. Ochrona zabytków, 2. - s. 86.

Jokilehto J., 1986. A History of Architectural Conservation. The University of York, England.

Latosinska J., Wlodarczyk B., 2015. Badania nad turystyczno-kulturalnym wykorzystaniem zamku w Inowłodzu w pierwszym roku po rekonstrukcji. Warsztaty z Geografii Turyzmu. s. 75-99.

Lübke W., 1861. Das Restaurationsfieber.

M_A_D_M_A_X, 2016. Nasledye. Olesko. Monastyr' kaputsynov + zamok/Spadshchyna. Oles'ko. Monastyr kaputsyniv + zamok. Part 1. [online] Available at: <https://m-a-d-m-ax.livejournal.com/363204.html> [Date of reference: 1 February 2021].

Mottl D., 2008. Trakai Island Castle. [online] Available at: $\langle$ https://commons.wikimedia.org/wiki/File:Trakai_Island_Castle.jpg $>$ [Date of reference: $\underline{2}$ February 2021]. 
Orda N., 1883. Trakai Island Castle in 19c. [online] Available at: <https://commons.wikimedia.org/wiki/File:Trakai_Island_Castle_in_19c.jpg>[Date of reference: $\underline{2}$ February 2021].

Pipe S., 2007. Woodstock's lost royal palace. [online] Available at: <http://www.bbc.co.uk/oxford/content/articles/2007/10/17/glyme_feature.shtml> [Date_of reference: 1 February 2021].

Polska-org, 2018. Zamek Królewski w Warszawie w 1947 roku. [online] Available at: <https://polska-org.pl/7144465,foto.html?idEntity=7118296> [Date of reference: 20 January 2021].

Polskie zamki, 2007. Zamek $w$ Inowlodzu. [online] Available at: <http://www.zamki.pl/?idzamku=inowlodz\&msg=0> [Date of reference: 2 February 2021].

Povilaityte E., 2016. The Conservation History, Problems and the Rehabilitatiom of Lithuanian Medival Castles. Procedia - Social and Behavioral Sciences, 225. s. 85-95.

Riaubiene E., 2012. Use of Architectural Heritage: Challenhes of Preservation and Adaptation. Architecture and Urban Planning, 6. s. 25-30.

Rostad B., 2013. Upper Castle in Vilnius. [online] Available at: <https://www.flickr.com/photos/brostad/9651317009/> [Date of reference: 2 February 2021].

Ruskin J., 1849. The semen Lamps of architektura. London.

The Yorck Project, 2002. Heidelberg Castle. [online] Available at: <https://commons.wikimedia.org/wiki/File:Carl_Philipp_Fohr_001.jpg> [Date of reference: 1 February 2021].

Tygodnik Ilustrowany, 1861. Vilnius Upper Castle, Lithuania. [online] Available at: <https://commons.wikimedia.org/wiki/File:View_of_Vilnius_Upper_Castle_with_remaining_Ged iminas_Tower.jpg > [Date of reference: 2 February 2021].

Warsawtour, 2020. Zamek Królewski $w$ Warszawie. [online] Available at: <https://warsawtour.pl/zamek-krolewski-w-warszawie-3/> [Date of reference: 20 January 2021].

Wolf R., 2005. Heidelberger Schloß, Gesamtansicht von NNW. [online] Available at: <https://commons.wikimedia.org/wiki/File:Heidelberg-Schlo\%C3\%9F.JPG> [Date of reference: 2 February 2021].

Zachwatowicz Jan., 1946. Program i zasady konserwacji zabytków. Biułetyn Historii Sztuki I Kultury, 1-2.

Kalyna-Theodora Gavryliv Graduate student of the Department of Architecture and Conservation Lviv Polytechnic National University, 12 Bandera St., Lviv 79013, Ukraine e-mail: kalyna.gavryliv@gmail.com ORCID: 0000-0001-7328-8349

\section{THE PROBLEM OF CASTLE RUINS RESTORATION WITHIN THE RESTORATION ACTIVITIES FORMATION}

(C) Gavryliv K.-T., 2020

The article reveals the history of the restoration activity formation on the example of the castle ruins restoration in Ukraine and Europe during the 19th-20th centuries.

Castles have been constantly transforming since their foundation. Each subsequent owner of the castle strengthened it, restored it after its destruction, made changes to the building architecture. And in the 19th century, an understanding of the value of such architectural objects was developed, and various methods for their preservation began to be proposed. Stylistic 
restorations are considered on the example of Trakai Island Castle (Lithuania) and Pierrefonds castle (France). Archaeological restorations aimed at conserving objects reflect the Upper Castle in Vilnius (Lithuania) and Heidelberg Castle (Germany). Scientifically based, the restoration is presented at facilities in Olesko Castle (Ukraine) and in Warsaw, Inovlodz (Poland). Woodstock Palace (England) is an example of the architectural monument destruction, and Tatar Tower of Ostroh Castle (Ukraine) is a symbol of a good future which is revealed in front of the castles in a state of long ruin. Positions on the restoration of architectural monuments have been analyzed by a number of scientists such as Eugène Emmanuel Viollet-le-Duc, Alois Riegl, Camillo Boito, Yan Zakhvatovich.

It was the restoration of the castle ruins that sparked a discourse on how to preserve architectural monuments. After all, a castle is one of the most complex types of structures, including its structure, location, and function. Since the beginning of their founding, castles have been the subject to constant interference with their material structure, which in the 19th century became more important than their utilitarian purpose. The conservation method comes out on top, but it is often paired with fragmentary restoration. In any case, the object must function and be visited, regardless of whether it is compositionally complete or fragmentarily preserved, because the interest in it ensures its further existence.

Keywords: restoration, conservation, reconstruction, ruin, castle ruin. 